\title{
EFL Students' Perceptions of the Effectiveness of Virtual Classrooms in Enhancing Communication Skills
}

\author{
Yousif A. Alshumaimeri ${ }^{1} \&$ Abeer M. Alhumud $^{1}$ \\ ${ }^{1}$ Curriculum and Instruction Department, Faculty of Education, King Saud University, Riyadh, Saudi Arabia \\ Correspondence: Yousif A. Alshumaimeri, Curriculum and Instruction Department, Faculty of Education, King \\ Saud University, Riyadh, 11625, Saudi Arabia.
}

Received: October 1, 2021

Accepted: October 22, 2021

Online Published: October 25, 2021

doi: $10.5539 /$ elt.v14n1 $1 \mathrm{p} 80$

URL: https://doi.org/10.5539/elt.v14n11p80

\begin{abstract}
This study aimed to examine students' perceptions of the effectiveness of virtual classrooms in enhancing their communication skills. Study participants were 43 female English majors at the College of Education at a Saudi Arabian university. This study was conducted during the first semester of the 2020/2021 academic year when COVID-19 restrictions necessitated online learning. The study implemented a mixed methodology approach in which qualitative and quantitative tools were used to collect data. Two data collection instruments were used: a questionnaire and observations. In the questionnaire findings, students identified lack of confidence, anxiety surrounding making mistakes, and lack of vocabulary as their greatest challenges when communicating in English. The questionnaire also revealed that students held positive attitudes towards the effectiveness of virtual classrooms in enhancing their oral communication skills. The observation data revealed that virtual classrooms can play a significant role in enhancing students' communication skills. However, despite their positive views of virtual classrooms, students agreed that the lack of face-to-face communication was a major obstacle in online learning.
\end{abstract}

Keywords: virtual classroom, e-learning, communication skills, undergraduate students, EFL, Saudi Arabia

\section{Introduction}

Communication skills are essential in human interaction. Acquiring high-level English communication skills can lead to better opportunities in both the personal and professional realm. In the classroom context, effective communication can positively impact the learning process. Communication skills encompass oral aspects, such as conversation, negotiation and discussion, and non-oral aspects, such as writing, facial expressions and body language. However, in the field of English as a foreign language (EFL), oral communication is the most challenging and complicated skill for most learners to master (Alhamdi, 2014; Alhosni, 2014; Alshumaimeri, 2019). Communication skills require more than just knowledge of the theoretical aspects of grammar and vocabulary; the ability to communicate means being able to express oneself clearly and appropriately (Al-Mahrooqi, 2012). Many factors, such as teaching methodologies, curriculum, time limitations and class size, affect the development of communication skills in the classroom. Accordingly, students need more practice opportunities to develop their communication skills. Web-based language learning can contribute to enhancing students' oral communication skills (Appel \& Borges, 2012).

The integration of information and communication technology into the educational system has significantly impacted teaching and learning. The use of technology, particularly the Internet, is popular in English language learning; it allows learners and teachers to practise the language in a non-traditional way. Combining online tools with language learning provides further opportunities for learners to practise communication skills (Alshumaimeri, 2019; Alswilem, 2019; Cong-Lem, 2018). In Saudi Arabia, e-learning was first used in 2002 and since then, it has had a considerable impact on the academic and educational fields (Alasmari \& Khan, 2014). Saudi Arabia has attempted to integrate technology into the educational system to achieve better student outcomes and keep abreast of global trends (Alshumaimeri, 2008; 2019; Alswilem, 2019).

Virtual classrooms are synchronous classrooms that allow instructors and students to interact in real time. Utilising virtual classrooms to teach English may help students develop different skills. However, due to the lack of face-to-face interaction, strong communication skills are crucial. Therefore, this study aimed to investigate the effectiveness of virtual classrooms in enhancing communication skills. In this study, English communication skills are defined as the manner in which students interact orally with the teacher and their peers in virtual classrooms. 


\subsection{Statement of the Problem}

Multiple studies have been conducted on the effectiveness of online classrooms in enhancing EFL communicative skills (Aljadili, 2015; Tazijan, Baharom, \& Shaari, 2016; Periasamy \& Poogodi, 2020); however, few were conducted in Saudi Arabia. Most employed an experimental design that did not provide insights into students' voices or language samples. From the researchers' perspective, it is important to shed light on students' perceptions regarding the effectiveness of online classrooms in enhancing their EFL communication skills. It is insufficient to say that this tool is effective based only on general achievement tests; it is necessary to consider users' beliefs and feelings as well. Thus, this study aimed to investigate the effectiveness of virtual classrooms in enhancing communication skills according to the perceptions of Saudi EFL students.

\subsection{Research Objectives}

The study aimed to

- identify common issues in oral English communication.

- examine students' perceptions of the effectiveness of virtual classes in enhancing their communication skills.

- examine the effectiveness of virtual classrooms in enhancing communication skills based on actual student performance.

\subsection{Research Questions}

This study attempted to answer the following questions:

- What common problems do students face in oral English communication?

- What are students' perceptions of the effectiveness of virtual classes in enhancing their English communication skills?

- Are virtual classes effective in enhancing EFL students' communication skills?

\subsection{Significance of the Study}

The study identifies the problems that students might face during communication practice. The study's findings may benefit EFL teachers and students by encouraging them to utilise virtual classrooms to improve oral communication skills.

\section{Literature Review}

\subsection{Virtual Classrooms}

Virtual classrooms provide an online environment for students and teachers to communicate synchronously using different features, such as audio calls and videoconferences (Parker \& Martin, 2010). Due to global technological and network advancements, virtual classrooms have emerged as a new method of teaching and learning (Yadav, 2016). A virtual classroom can be defined as a web-based classroom that teachers and students can access via personal computers or mobile devices (Montoute, 2013). According to Çakýroglu (2014), the synchronous setting of virtual classrooms is one of their main similarities to real classrooms, and Hussein (2016) stated that virtual classrooms offer different teaching and learning opportunities than traditional classrooms.

Danesh, Bailey and Whisenand (2015) stated that virtual classes can improve communication skills because these classes aid in the development of speaking skills. According to Rouse (2016), virtual classrooms are flexible, affordable, practical and easy to access. Yadav (2016) illustrated the benefit of virtual classrooms in removing geographical barriers, reducing anxiety and enhancing motivation among students, which may help improve communication skills. According to Al-Asmari and Khan (2014), the main advantages of virtual classrooms are the flexibility and convenience they offer, especially for students who live in distant locales. Furthermore, virtual classrooms are suitable for students who might feel too shy to participate in classroom discussions. Berry (2019) pointed out that features used in the virtual classroom, such as audio or video calls, give students an opportunity for constant interaction, increasing their engagement and sense of community. According to Pan and Sullivan (2005), in synchronous classrooms, being able to speak with the instructor or a classmate in real time has a positive impact on the interaction. Yilmaz (2015) stated that virtual classrooms are similar to traditional classrooms in terms of giving feedback, the interaction between teachers and students, and classroom activities.

However, there are some limitations to virtual classes. Technical problems are a critical issue in online learning that can create a negative experience for students. In addition, this type of classroom may not suit all learning styles, though advancements in technology could address these challenges (Manegre \& Sabiri, 2020). Furthermore, 
teachers and students are more familiar with the traditional classroom than the virtual classroom, which might affect how the technology is used (Yadav, 2016). Therefore, teachers and students should be trained in using virtual classrooms. To have an effective virtual learning environment, instructors and students must have a stable internet connection as well as clear instruction and guidance for online classes (Manegre \& Sabiri, 2020).

\subsection{Communication Skills in EFL Classrooms}

Communication means sending, receiving or exchanging ideas, information or messages verbally or nonverbally. It can be categorised as verbal, written, or nonverbal; it also involves listening and giving feedback. Therefore, communication skills are crucial for English learners (Wambui, 2012). However, developing and practising oral communication skills in the classroom can be challenging (Cheekeong, Yassin, \& Abdulrahman, 2014). According to Cheekeong et al. (2014), there are three factors related to EFL oral communication issues: teachers, curriculum and students. They argued that teachers do not encourage students to speak and employ ineffective strategies for improving communication skills. Moreover, students can be afraid to participate in classroom discussions because they lack confidence and want to avoid mistakes. The authors also argued that the EFL curriculum typically focuses on the theoretical aspects of language. Abu Alyan (2013) reported that a limited vocabulary, lack of extensive listening and reading exposure, interference of L1 and lack of confidence are the major reasons for students' weak oral communication skills. Accordingly, students can develop their skills if given quality opportunities to communicate (Khambayat, 2017). In communicative situations, as Khamkhien (2011) stated, students are sometimes unable to use the correct target language even if they possess linguistic knowledge. Thus, linguistic knowledge is insufficient for communication; practise is key. According to AlSaleem (2018), oral communication skills require high levels of mental and cognitive processing as well as linguistic abilities in vocabulary, pronunciation and grammar. In the classroom context, English teachers can employ various methods, including discussions, role plays, demonstrations and group work (Khambayat, 2017), to help students enhance their communication skills. Thakur, AlMashani and Almashikhi (2019) suggested that students could develop communication skills if they were engaged in natural language practice and proposed that classroom projects could allow students to use language more effectively.

An alternative method for improving communication skills is virtual classes. According to Parker and Martin (2010), online classes enable students to communicate with each other as if they were in the classroom. Additionally, Çakýroglu (2014) stated that virtual classrooms can facilitate and enhance communication among students if the instructor provides a highly interactive setting. Yadav (2016) pointed out that although communication in virtual classrooms is not as rich as in traditional classes, it can nonetheless help learners develop their skills.

\subsection{The Effectiveness of Virtual Classrooms on EFL Students' Communication Skills}

Technological developments have created a shift from traditional to internet-based classrooms. Therefore, questions have emerged about the effectiveness of virtual classrooms in enhancing students' skills, and multiple qualitative and empirical studies have investigated this topic. While several studies showed students' preference for online learning, a lack of face-to-face communication can make it difficult to establish and nurture relationships with teachers and peers. The literature showed that online learning helps students improve their skills and increases their confidence. A case study by Abu Baker, Latiff and Hamat (2013) examined the perceptions of 11 EFL students with low proficiency levels after they engaged with an asynchronous discussion tool to develop their oral communication skills. The results showed that the majority of students felt more comfortable and confident communicating in online classrooms than in face-to-face settings. The participants agreed that in face-to-face communication, they were afraid of being judged by their classmates when speaking English. The researchers argued that when physical barriers are reduced, online learning platforms can offer opportunities for students to improve their oral skills.

A study by Salbego and Tumolo (2015) recorded the perceptions of 10 teachers and students with experience in traditional and virtual classrooms. The aim was to compare the characteristics, advantages and disadvantages of these two settings. Participants were asked to answer an online questionnaire regarding their experience with Skype voice call classes compared to traditional classes. The study findings showed that all participants had a positive view of online classes. They felt that speaking and listening were the focus in the virtual classroom because they needed to listen carefully and frequently ask for clarification. In addition, students agreed that they felt more comfortable speaking in online classes than in traditional classes. However, some students shared that the lack of face-to-face communication and technical issues were major obstacles to improving their communication skills. The researchers stated that teachers should emphasise speaking and listening skills in online classes, as these skills can be hard to develop in traditional classrooms. 
A case study by Banditvilai (2016) investigated the impact of supplemental online courses on students' English skills. The researcher divided 60 participants into two groups of 30 students each. Both groups followed the same course in a classroom setting, but the control group took a supplemental online course. The study utilised pre- and post-tests, a questionnaire and interviews. Although the study revealed a positive attitude towards online learning, the results illustrated that a lack of face-to-face communication may contribute to feelings of social disconnection and might inhibit valuable interaction between teachers and students.

A Turkish study conducted by Istifci (2017) investigated 167 students' preferences for face-to-face, blended, and fully online learning. Data were collected through a questionnaire and interviews. Participants were asked to complete the questionnaire, and then 10 students from the sample were randomly chosen for the interview. The majority of students reported a preference for traditional classrooms when asked about participating in classroom discussions. The interviews revealed that students felt a traditional classroom setting would make it easier to establish positive interpersonal relationships with teachers, build on their knowledge and ask questions.

It is also important to review literature that is relevant to the context of this study. In the Saudi Arabian context, an experimental study by Alshahrani (2016) was conducted to investigate the effect of synchronous videoconferencing on enhancing 36 EFL students' speaking skills. The study sample was divided into experimental and control groups. The experimental group followed a videoconferencing course for 12 weeks, while the control group took a regular classroom course. The study used pre- and post-tests, video recordings and interviews as tools for data collection. Both groups showed the same results on the pre-test; on the post-test, however, the experimental group scored higher, especially on the oral skills components. Overall, the study revealed positive attitudes towards online learning. Furthermore, the study highlighted that online videoconference classrooms can help students improve their speaking skills and increase their confidence.

Alhawiti (2017) conducted a study that examined the effect of virtual learning on students' achievement in English. Study participants were 50 students who were divided into control and experimental groups. Those in the experimental group were enrolled in virtual classes, while the control group studied in a traditional classroom. The findings revealed that the experimental group showed better performance in English skills, including oral communication.

AlQahtani (2019) conducted a quantitative study to obtain feedback on virtual classrooms from 15 English teachers and 15 undergraduate students at King Khalid University. The researcher distributed a questionnaire to the two groups. The findings concluded that $57 \%$ of students had positive feelings about virtual learning. Moreover, most students felt more confident about speaking in a virtual classroom than in a traditional one. However, some students stated that virtual classrooms were not effective in improving their communication skills. In the same study, the majority of teachers agreed on the usefulness of online classes in supporting communication.

An experimental study by Hamouda (2020) examined the impact of virtual classrooms on improving speaking skills. The study included both quantitative and qualitative data. Study participants were divided into experimental and control groups, each with 35 English majors from Al-Qassim University. Both groups studied the same listening and speaking topics; however, the control group studied in traditional classrooms while the experimental group learned virtually. In addition, the experimental group was surveyed and interviewed to obtain feedback after the experience. The findings concluded that virtual classes had a significant impact on students' speaking skills and gave students more freedom to express their views. The researcher concluded that virtual classes can provide a relaxing environment for English learners.

Overall, previous studies have examined the impact of online learning in enhancing EFL students' oral skills. While some Saudi Arabian studies have highlighted the impact of virtual classrooms on students' oral skills (Alshahrani, 2016; AlQahtani, 2019; Hamouda, 2020), it is clear that a gap still exists in the literature in terms of exploring the effectiveness of virtual classrooms in enhancing EFL students' communication skills from the perspective of the students themselves. Therefore, there is a need for further study in this area.

\section{Method}

\subsection{Research Design}

This study employed a mixed methods design, using both quantitative and qualitative data to investigate the effectiveness of virtual classrooms in enhancing EFL students' communication skills. The mixed methods approach can be described as the integration of quantitative and qualitative methods of data collection and analysis to provide a better understanding of the study's purpose (Clark \& Ivankova, 2015). Therefore, this approach was chosen in order to validate the quantitative data collected from the questionnaire by conducting classroom observations. 


\subsection{Population and Study Sample}

The study population was undergraduate female English majors in the Curriculum and Instruction Department of the College of Education in a Saudi university in Riyadh during the first semester of the 2020/2021 academic year. The whole population, which consisted of 43 students, was used as a sample in the study. However, 22 students were observed for classroom observation due to the institution's regulations and accessibility restrictions. Therefore, convenience sampling was used.

\subsection{Instruments}

Two instruments were used to collect the research data: a questionnaire and classroom observations.

\subsubsection{Questionnaire}

The study questionnaire was self-created and consisted of 27 statements. Its design was based on an extensive review of relevant studies in the fields of virtual classrooms, online learning and EFL communication skills. The statements were reviewed by three experts in teaching English to speakers of other languages and applied linguistics. The questionnaire was divided into two sections: the first aimed to identify EFL students' oral communication problems, and the second aimed to elicit students' perceptions of the effectiveness of virtual classrooms in enhancing their communication skills. Participants were asked to respond to each statement using a five-point Likert scale (strongly agree - agree - neutral - disagree - strongly disagree). Additionally, the following descriptive statistics and correlation analyses were used.

3.3.1.1 Validity of the Internal Consistency of the Study Tool

The researcher calculated the Pearson correlation coefficient between each item and the total degree of the dimension. Results are presented in the following tables.

Table 1. Pearson correlation coefficients between each statement and the total degree of domain

This section aims to identify students' oral communication problems

\begin{tabular}{lll}
\hline Item & Pearson correlation coefficient & P-value (Sig) \\
\hline 1 & 0.352 & 0.020 \\
2 & 0.885 & 0.000 \\
3 & 0.591 & 0.000 \\
4 & 0.629 & 0.000 \\
5 & 0.711 & 0.000 \\
6 & 0.611 & 0.000 \\
7 & 0.523 & 0.000 \\
8 & 0.434 & 0.002 \\
9 & 0.443 & 0.001 \\
10 & 0.524 & 0.000 \\
11 & 0.635 & 0.000 \\
12 & 0.318 & 0.019 \\
13 & 0.421 & 0.002 \\
14 & 0.332 & 0.015 \\
\hline
\end{tabular}

Table 1 illustrates a statistically significant relationship between each item and the total degree of dimension. 
Table 2. Pearson correlation coefficients between each statement and the total degree of domain

This section aims to elicit students' perceptions of the effectiveness of virtual classrooms in enhancing their communication skills

\begin{tabular}{lll}
\hline Item & Pearson correlation coefficient & P-value (Sig) \\
\hline 1 & 0.462 & 0.001 \\
2 & 0.571 & 0.000 \\
3 & 0.605 & 0.000 \\
4 & 0.827 & 0.000 \\
5 & 0.603 & 0.000 \\
6 & 0.655 & 0.000 \\
7 & 0.771 & 0.000 \\
8 & 0.420 & 0.004 \\
9 & 0.320 & 0.005 \\
10 & 0.436 & 0.002 \\
11 & 0.783 & 0.000 \\
12 & 0.746 & 0.000 \\
13 & 0.840 & 0.000 \\
\hline
\end{tabular}

Table 2 illustrates a statistically significant relationship between each item and the total degree of dimension.

Table 3. Pearson correlation coefficients between each domain and the total degree of measure

\begin{tabular}{llc}
\hline Domain & Pearson correlation coefficient P-value (Sig) \\
\hline This section aims to identify students' oral communication problems & $0.754^{* *}$ & 0.000 \\
$\begin{array}{l}\text { This section aims to elicit students' perceptions of the effectiveness of } \\
\text { virtual classrooms in enhancing their communication skills }\end{array}$ & $0.899^{* *}$ & 0.000
\end{tabular}

Table 3 indicates a statistically significant relationship between each domain and the total degree of measure. Therefore, as presented in Tables 1, 2 and 3, the correlation analyses show that the two questionnaire sections have a high internal consistency of validity.

\subsubsection{Reliability of the Questionnaire}

The reliability of the study tool refers to the degree to which the tool presents similar results in repeated trials (Creswell, 2011).

Table 4. Cronbach's alpha reliability coefficients

\begin{tabular}{lll}
\hline Dimension & Item & Cronbach's alpha coefficients \\
\hline This section aims to identify students' oral communication problems & 14 & 0.764 \\
This section aims to elicit students' perceptions of the effectiveness of & 13 & 0.788 \\
virtual classrooms in enhancing their communication skills & 27 & 0.776 \\
Overall reliability coefficient & & \\
\hline
\end{tabular}

Table 4 shows that the overall reliability coefficient is $(0.776)$, indicating that the tool has great stability.

Table 5. Kaiser-Meyer-Olkin (KMO) measure of sampling adequacy

KMO measure of sampling adequacy $\quad 0.695$

Table 5 shows that the $\mathrm{KMO}$ value is 0.695 , meaning that the sample size is large enough. 
Table 6. Interpretation of mean score

\begin{tabular}{ll}
\hline Mean score & Interpretation of mean score \\
\hline $1.00-1.79$ & Strongly disagree \\
$1.80-2.59$ & Disagree \\
$2.60-3.39$ & Neutral \\
$3.40-4.19$ & Agree \\
$4.20-5.00$ & Strongly agree \\
\hline
\end{tabular}

As presented in Table 6, the mean scores were divided into five ranges:

* If the mean is $1.00-1.79$, the interpretation is strongly disagree.

* If the mean is $1.80-2.59$, the interpretation is disagree.

* If the mean is $2.60-3.39$, the interpretation is neutral.

* If the mean is 3.40-4.19, the interpretation is agree.

* If the mean is $4.20-5.00$, the interpretation is strongly agree.

\subsubsection{Observations}

Classroom observations were used to collect information about the effectiveness of virtual learning and compare students' perceptions to their actual performance. The researchers observed the performance of 22 students over different sessions. The virtual sessions were conducted via Zoom, and each was audio-recorded to ensure that all the data were gathered in a natural setting (Nordstrom, 2015). The observations were conducted on different days throughout the course of the study: September 16, October 28, November 2 and November 30, 2020 (hereafter referred to as Sessions 1, 2, 3 and 4, respectively). Sessions 1, 2 and 3 took place in a class of 12 students, and Session 4 took place in a class of 10 students. Sessions 1 and 2 involved presentations by the lecturer, whereas Sessions 3 and 4 included student presentations. Sessions 1 and 2 lasted for approximately 45 minutes, starting at 1:00 p.m. and ending at 1:45 p.m. Sessions 3 and 4 were student presentations, and both lasted for 10 to 15 minutes. Audio calls and PowerPoint slides were used in each session. Sessions 1, 2 and 3 were about teaching and learning English, while Session 4 covered computer-assisted language learning. In Sessions 1 and 2, the lecturer presented new teaching methods to the students. In Session 3, two students were asked to employ one of the teaching methods (role playing) with their classmates, while in Session 4, two students were tasked with discussing a language-learning app. The data collected from the observations were recorded and transcribed. The students who gave presentations are referred to as presenters in the transcript.

\subsection{Data Analysis Process}

The data collected from the questionnaire were statistically analysed using Statistical Package for the Social Sciences (SSPS), while data collected from the observation were qualitatively analysed using thematic analysis. Thematic analysis of the data followed these steps: the transcription was read thoroughly, repeated patterns were coded, similar codes were grouped into categories and finally, several themes emerged: student engagement, lecturer-student interaction, student-student interaction and oral linguistic issues.

\section{Research Findings and Analysis}

\subsection{Results Related to the First and Second Research Questions}

To answer the research questions, participants' questionnaire responses were calculated using means and standard deviation. 


\subsubsection{Results Related to Common Problems Students Face in Oral English Communication}

Table 7. Analysis of common problems students face when communicating in English

No. Item

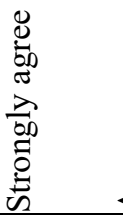

Feedback on my oral mistakes is very helpful in 18 improving my communication skills.

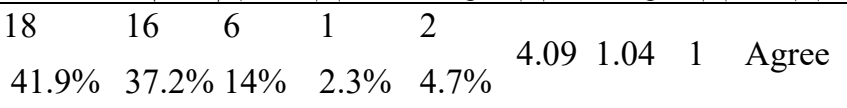

Being anxious about making mistakes makes it

5 difficult for me to practise oral communication in the classroom.

$\begin{array}{lllllllll}19 & 13 & 8 & 1 & 2 & & \\ 44.2 \% & 30.2 \% & 18.6 \% & 2.3 \% & 4.7 \% & & & & \end{array}$ A lack of confidence is my major problem when $\begin{array}{llllll}12 & 16 & 10 & 4 & 1\end{array}$

4 communicating in English.

$\begin{array}{lllllllll}12 & 16 & 10 & 4 & 1 & 3.79 & 1.04 & 3 & \text { Agree } \\ 27.9 \% & 37.2 \% & 23.3 \% & 9.3 \% & 2.3 \% & & & & \end{array}$

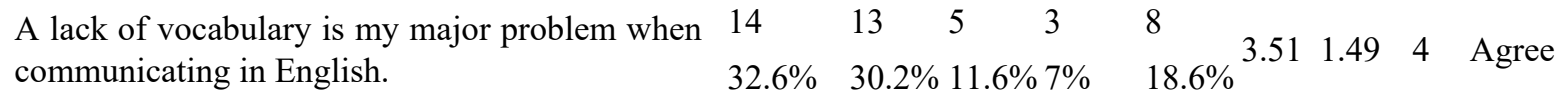
$\begin{array}{lllllll}\text { My instructor rarely applies different methods } & 3 & 17 & 17 & 5 & 1\end{array}$

6 and techniques to encourage communication among students.

$7 \%$

$$
39.5 \% 39.5 \% 11.6 \% 2.3 \%
$$

$\begin{array}{llll}3.37 & 0.87 & 5 & \text { Neutral }\end{array}$

Making pronunciation mistakes is my major 1 problem when communicating in English.

My instructor rarely tries to initiate students' interaction.

$$
25.6 \%
$$

$$
\begin{array}{llll}
8 & 11 & 10 \quad 3
\end{array}
$$

$18.6 \% 25.6 \% 23.3 \% 7 \%$
$4 \quad 11 \quad 21 \quad 7 \quad 0$

$9.3 \% \quad 25.6 \% 48.8 \% 16.3 \% 0.0 \%$ $\begin{array}{llll}3.33 & 1.29 & 6 & \text { Neutral }\end{array}$ $\begin{array}{llll}3.28 & 0.85 & 7 & \text { Neutral }\end{array}$

The techniques and methods my instructors use 2 do not encourage communication practice.

$$
4.7 \%
$$$$
\begin{array}{llll}
18 & 13 & 10 & 0
\end{array}
$$

4 Arabic is used too much in our English classes.

$$
\begin{aligned}
& 8 \\
& 18.6 \%
\end{aligned}
$$$$
41.9 \% 30.2 \% 23.3 \% 0.0 \%
$$$$
\begin{array}{llll}
3.28 & 0.88 & 8 & \text { Neutral }
\end{array}
$$

Classroom activities rarely focus on enhancing oral communication skills.

$$
\begin{aligned}
& 0 \\
& 0.0 \%
\end{aligned}
$$$$
13
$$$$
15
$$$$
56
$$$$
30.2 \% 25.6 \% 11.6 \% 14 \%
$$$$
\begin{array}{llll}
3.28 & 1.30 & 9 & \text { Neutral }
\end{array}
$$

I do not like when instructors correct my oral 1 mistakes.

$$
23.3 \%
$$$$
\begin{array}{llll}
18 & 17 & 7 & 1
\end{array}
$$$$
41.9 \% 39.5 \% 16.3 \% 2.3 \%
$$$$
\begin{array}{llll}
3.21 & 0.80 & 10 & \text { Neutral }
\end{array}
$$

Making grammatical mistakes is my major problem when communicating in English.

\section{2}

$4.7 \%$

$\begin{array}{llll}7 & 9 & 10 & 7\end{array}$

$16.3 \% 20.9 \% 23.3 \% 16.3 \%$

$3.07 \quad 1.42 \quad 11$ Neutral

$\begin{array}{llll}13 & 16 & 8 & 4\end{array}$

The classroom environment does not help me participate in discussions.

$2 \quad 10 \quad 13 \quad 15 \quad 3$

$4.7 \%$

$23.3 \% 30.2 \% 34.9 \% 7 \%$

$2.84 \quad 1.02 \quad 13$ Neutral

12 Instructors rarely correct my oral mistakes.

$$
\begin{array}{lllllllll}
3 & 8 & 13 & 12 & 7 & 2.72 & 1.16 & 14 & \text { Neutral } \\
7 \% & 18.6 \% & 30.2 \% & 27.9 \% & 16.3 \%
\end{array}
$$

\section{Overall mean}

3.351 .09 - Neutral

The overall mean is 3.35 , illustrating that students have neutral attitudes towards their own oral communication problems. The highest mean score, 4.09, indicates that students agreed that feedback helps them improve their communication skills. Students' anxiety surrounding making mistakes was ranked second, with a mean score of 4.07, as three-quarters of the participants agreed or strongly agreed with the statement. Lack of confidence when communicating in English was ranked third, with a mean score of 3.79, where more than half of the participants agreed or strongly agreed with the statement. The fourth issue that students faced in practising their communication skills was a lack of vocabulary, with a mean score of 3.51. The lowest score was assigned to the statement 'Instructors rarely correct my oral mistakes', with a mean score of 2.72 . 
4.1.2 Results Related to Students' Perceptions of the Effectiveness of Virtual Classrooms in Enhancing Their Communication Skills

Table 8. Analysis of students' perceptions of the effectiveness of virtual classrooms in enhancing their communication skills

\begin{tabular}{|c|c|c|c|c|c|c|c|c|c|c|}
\hline No. & Item & 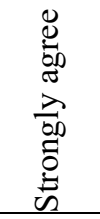 & 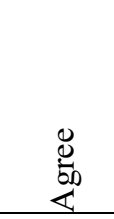 & $\overline{\overparen{\pi}}$ & 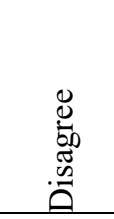 & 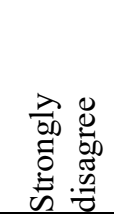 & $\sum_{\tilde{E}}^{\approx}$ & 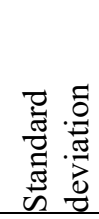 & 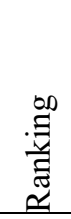 & 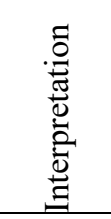 \\
\hline 5 & $\begin{array}{l}\text { I feel more engaged in conversations and } \\
\text { discussions in virtual classes than in traditional } \\
\text { classes. }\end{array}$ & $\begin{array}{l}19 \\
44.2 \%\end{array}$ & $\begin{array}{l}13 \\
30.2 \%\end{array}$ & 7 & $\begin{array}{l}4 \\
9.3 \%\end{array}$ & $\begin{array}{l}0 \\
0.0 \%\end{array}$ & 4.09 & 1.00 & 1 & Agree \\
\hline 1 & $\begin{array}{l}\text { Virtual classrooms make me feel more comfortable } \\
\text { participating in classroom discussions. }\end{array}$ & $\begin{array}{l}18 \\
41.9 \%\end{array}$ & $\begin{array}{l}9 \\
20.9 \%\end{array}$ & $\begin{array}{l}9 \\
20.9 \%\end{array}$ & $\begin{array}{l}6 \\
14 \%\end{array}$ & $\begin{array}{l}1 \\
2.3 \%\end{array}$ & 3.86 & 1.19 & 2 & Agree \\
\hline 6 & $\begin{array}{l}\text { Virtual classrooms make me feel more motivated } \\
\text { to participate in discussions. }\end{array}$ & $\begin{array}{l}16 \\
37.2 \%\end{array}$ & $\begin{array}{l}11 \\
25.6 \%\end{array}$ & $\begin{array}{l}9 \\
20.9 \%\end{array}$ & $\begin{array}{l}7 \\
16.3 \%\end{array}$ & $\begin{array}{l}0 \\
0.0 \%\end{array}$ & 3.84 & 1.11 & 3 & Agree \\
\hline 13 & $\begin{array}{l}\text { Virtual classrooms play a significant role in } \\
\text { improving my oral communications skills. }\end{array}$ & $\begin{array}{l}14 \\
32.6 \%\end{array}$ & $\begin{array}{l}12 \\
27.9 \%\end{array}$ & $\begin{array}{l}13 \\
30.2 \%\end{array}$ & $\begin{array}{l}4 \\
9.3 \%\end{array}$ & $\begin{array}{l}0 \\
0.0 \%\end{array}$ & 3.84 & 1.00 & 4 & Agree \\
\hline 8 & $\begin{array}{l}\text { The lack of face-to-face communication makes it } \\
\text { difficult to participate in discussions. }\end{array}$ & $\begin{array}{l}18 \\
41.9 \%\end{array}$ & $\begin{array}{l}7 \\
16.3 \%\end{array}$ & $\begin{array}{l}8 \\
18.6 \%\end{array}$ & $\begin{array}{l}10 \\
23.3 \%\end{array}$ & $\begin{array}{l}0 \\
0.0 \%\end{array}$ & 3.77 & 1.23 & 5 & Agree \\
\hline 12 & $\begin{array}{l}\text { I think virtual classrooms can help me overcome } \\
\text { my oral communication issues. }\end{array}$ & $\begin{array}{l}12 \\
27.9 \%\end{array}$ & $\begin{array}{l}12 \\
27.9 \%\end{array}$ & $\begin{array}{l}13 \\
30.2 \%\end{array}$ & $\begin{array}{l}6 \\
14 \%\end{array}$ & $\begin{array}{l}0 \\
0.0 \%\end{array}$ & 3.70 & 1.04 & 6 & Agree \\
\hline 2 & $\begin{array}{l}\text { In virtual lessons, it is easier to interact with my } \\
\text { instructors and peers. }\end{array}$ & $\begin{array}{l}13 \\
30.2 \%\end{array}$ & $\begin{array}{l}12 \\
27.9 \%\end{array}$ & $\begin{array}{l}9 \\
20.9 \%\end{array}$ & $\begin{array}{l}9 \\
20.9 \%\end{array}$ & $\begin{array}{l}0 \\
0.0 \%\end{array}$ & 3.67 & 1.13 & 7 & Agree \\
\hline 4 & $\begin{array}{l}\text { I feel more confident when I speak in virtual } \\
\text { classrooms. }\end{array}$ & $\begin{array}{l}16 \\
37.2 \%\end{array}$ & $\begin{array}{l}9 \\
20.9 \%\end{array}$ & 7 & $\begin{array}{l}9 \\
20.9 \%\end{array}$ & $\begin{array}{l}2 \\
4.7 \%\end{array}$ & 3.65 & 1.31 & 8 & Agree \\
\hline 3 & $\begin{array}{l}\text { Commenting on what my instructors and peers say } \\
\text { is more comfortable in virtual classes than in the } \\
\text { classroom. }\end{array}$ & $\begin{array}{l}15 \\
34.9\end{array}$ & $\begin{array}{l}8 \\
18.6\end{array}$ & $\begin{array}{l}9 \\
20.9 \%\end{array}$ & $\begin{array}{l}11 \\
25.6 \%\end{array}$ & $\begin{array}{l}0 \\
0.0 \%\end{array}$ & 3.63 & 1.22 & 9 & Agree \\
\hline
\end{tabular}

There is no difference between traditional and

10 virtual classrooms in improving my communication skills.

$\begin{array}{lllllllll}12 & 10 & 9 & 6 & 6 & 3.37 & 1.40 & 10 & \text { Neutral } \\ 27.9 \% & 23.3 \% & 20.9 \% & 14 \% & 14 \% & & & \end{array}$

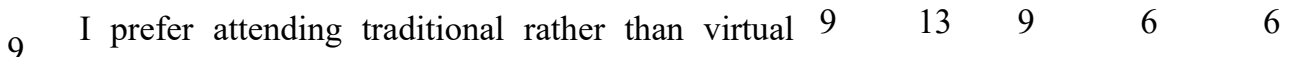
classes.

$20.9 \% 30.2 \% 20.9 \% \quad 14 \% \quad 14 \%$

$3.301 .34 \quad 11 \quad$ Neutral

$\begin{array}{lllllll}\text { In virtual classrooms, there are more opportunities } & 9 & 13 & 6 & 11 & 4\end{array}$

for me to speak than in traditional classrooms.

$20.9 \% 30.2 \% 14 \%$

$25.6 \% \quad 9.3 \%$

$\begin{array}{llll}3.28 & 1.32 & 12 & \text { Neutral }\end{array}$

Using virtual classrooms helps me discover my $\begin{array}{llllll}5 & 3 & 5 & 19 & 11\end{array}$

11 communication problems.

$11.6 \% \quad 7 \% \quad 11.6 \% \quad 44.2 \% \quad 25.6 \%$

$2.351 .27 \quad 13$ Disagree

Overall mean

3.571 .19 - Agree

The overall mean score is 3.57 , indicating that students have positive attitudes about the effectiveness of virtual classrooms in enhancing their communication skills. The highest mean score, 4.09, illustrates that students felt more engaged in virtual classroom discussions. The findings also revealed that students felt more comfortable participating in virtual classroom sessions, with a mean score of 3.86. A similar mean score of 3.84 shows that virtual classrooms motivated students to participate in discussions and that students agreed on the effectiveness of virtual classrooms in improving their oral communication skills. However, almost half of the participants strongly agreed that the lack of face-to-face communication was a major obstacle in virtual classroom communication, with a mean score of 3.77. In addition, the findings showed that the statement 'I feel more confident when I speak in 
virtual classrooms' had a mean score of 3.65 , as more than half of the participants either agreed or strongly agreed with this statement.

Furthermore, students displayed a neutral attitude towards their preference for traditional versus virtual classroom settings, with a mean score of 3.77. Students also had neutral responses to the statement 'In virtual classrooms, there are more opportunities for me to speak than in traditional classrooms,' which garnered a mean score of 3.28. On the other hand, the statement 'Using virtual classrooms helps me discover my communication problems' had the lowest mean score, 2.35; more than half of the participants disagreed and strongly disagreed with this statement.

\subsection{Results Related to the Effectiveness of Virtual Classrooms in Enhancing EFL Communication Skills}

The researcher observed and recorded the performance of 22 students from the total sample during four virtual sessions, taking note of the students' engagement with one another, their interactions with the lecturer and their peers, and their linguistic issues. In addition, the researcher analysed the data by extracting some examples from the transcription.

\subsubsection{Students' Engagement}

Students' engagement during the sessions was analysed thematically through their immediate responses to the lecturer's questions and their participation in classroom activities. All sessions were conducted via audio calls; thus, the level of engagement was measured through oral interaction only. In all sessions, students showed an acceptable level of engagement with the given topics. Most students spoke at least once during the sessions; most were willing to participate freely, while some were asked to answer after their names had been called. This exchange from Session 1 illustrates how students quickly responded to the questions.

- Lecturer: Okay, what is the basic rule in the direct method? You remember in the grammar translation method, how did they teach English? Through what?

- Student: Through a text or a passage.

- Lecturer: Yes, what did they have to do with this passage?

- Students: Translate it. / Another student: Translation.

In some cases, students paused after the lecturer asked questions. These pauses were indicated by the researcher in the transcript. This hesitation was mainly due to a lack of knowledge or lack of understanding of the questions. The lecturer simplified the questions or offered encouragement to motivate students to answer. For example, when students did not respond to some of the lecturer's questions in Sessions 1 and 2, the lecturer encouraged them to answer (e.g., 'Okay girls, try', 'Come on, girls', 'Give it a try'). In addition, the data below show how the lecturer posed the same question differently to encourage student interaction.

- Lecturer: Okay, what is the nature of teacher-student interaction, and what is the nature of student-student interaction? (pause) What did you realise? Is it teacher-student? Student-student? What do you think?

- Student: From teacher to students.

- Another student: Vice versa.

- Lecturer: Both. The interaction goes both ways, from teacher to students and students to teacher.

Another aspect of student engagement was participation in classroom activities. For example, students were often asked to read from slides during the sessions. The lecturer also planned activities for the students, such as showing them images of different classroom situations and asking students to comment on them.

- Lecturer: Okay, so from the beginning, what can you realise? What is a big map considered as? What is it?

- Student: A visual aid.

- Lecturer: Yes, excellent. The use of visual aid, so we can realise the use of the visual aids. Who can read this? (Calls students by name)

- Student reads: At the beginning of the class, the teacher asks students to read aloud a passage about United States geography.

- Lecturer: Okay, what skill is used now?

- Student: Reading. 


\subsubsection{Interaction Between Lecturer and Students}

The second theme was students' oral interactions with the lecturer, analysed via their questions and answers during the lessons. During Sessions 1 and 2, communication was directed from the lecturer to the students as the lecturer provided knowledge, explained points and asked questions. The lecturer's explanations were elaborate; she provided several details when giving definitions, as shown in this example from Session 2:

- Lecturer: In short, being able to communicate requires more than linguistic competence. It requires communicative competence. So being able to communicate is not only knowing the linguistic competence - knowing the vocabulary, the grammar. But what is more important? The communicative competence.

Students' responses, ranging from short answers to full sentences, were elicited primarily through wh- questions, and the lecturer had prior knowledge of the answers. However, there was no indication that the questions required students to express themselves or their opinions regarding the topics, as far as the researcher observed. The following are two examples of the lecturer's questions:

- Lecturer: There is something important about this. Why does the teacher ask the students to order the sentences? It helps in knowing what?

- Student: The order of the sentence.

- Another student: The correct order of the sentence.

- Lecturer: What is the difference here from the grammar translation method? Who can tell me?

- Student: In the grammar translation, they used the mother tongue, but here they should speak in the target language.

In some instances, when students did not understand the question, the lecturer modified or simplified the language used. For example, Session 1 included the word 'realia', which was a new word for the students. The example below shows how the lecturer tried to explain the meaning in simpler terms.

- Lecturer: So what is the meaning of realia? (pause) Do you have any ideas? Realia? It comes from which word?

- Students: Reality? Real?

- Lecturer: Real...So it is a real object. Teachers can bring real objects to the classroom to explain the meaning of a word. For example, a real apple. Bringing a real apple to explain the word apple or for example, a pin, a book, or something like that. Something real, that's what we call realia. So bring real objects to convey the meaning.

In addition, students communicated with the lecturer by asking for further clarification or discussing points raised, although their questions were few. The researchers noted the following in Session 1:

- Lecturer: Okay, so when the teacher once explains something, she will not use the native language to say the meaning of the word, okay? She will use the target language to demonstrate, whether drawing a picture, okay? Bring something real, a real object, you get it?

- Student: Yeah.

- Student: Miss! Is it like using synonyms? Like I use synonyms in the target language?

\subsubsection{Interaction Among Students}

Student-to-student interaction was analysed via students' discussions with one another - specifically their answers, comments and discussions of certain points - in the virtual classroom setting. Oral communication between students took place during the student presentations in Sessions 3 and 4. In Session 3, two students employed a teaching methodology and practised it with their classmates through a role-playing activity. In Session 4, two students were asked to introduce an English learning app and discuss its advantages and disadvantages.

In Session 3, students showed positive engagement with the presentation and the activities. For example, when the presenters asked, 'Who wants to read/answer/participate?', immediate responses followed. Moreover, students showed good oral communication skills during the activities. For example, Presenter 2 in Session 3 was asked to repeat the question to clarify exactly what was requested. Presenter 2 tried to negotiate the meaning by simplifying the question and adding more information. This is illustrated in the data below:

- Presenter 2: (voice was not clear) ....in the last picture. Tell me what the son will do after that. 
- Student: He will celebrate his birthday!

- Another student: He will blow the candle!

- Presenter 2: Um... and also? Can you see the last picture? ... (voice was not clear)

- Student: Can you repeat the question?

- Presenter 2: Okay. Can you predict what will happen after the father lights the candle on the cupcake?

In Session 4, two students presented a language learning app called Z American English to their classmates. The presenters introduced the app and discussed its advantages and disadvantages. Despite some grammatical issues, the language was understandable. However, students had limited engagement with the presentation: student participation was limited to one presenter asking for opinions of the app at the end of the presentation.

\subsubsection{Students' Oral Linguistic Issues}

Oral linguistic issues were analysed according to the number of linguistic mistakes students made. Pronunciation problems and native language interference were the most commonly observed issues. Regarding grammar, most students' answers were quite short; therefore, structural mistakes were hard to identify. The researchers twice observed interference of the first language (L1) with the target language (in Sessions 1 and 2). The extraction below, from Session 2, is an example of students' L1 interference with English. The student in this example asked the lecturer if it was possible to answer the question in Arabic.

- Lecturer: Do you know the difference between cohesion and coherence?

- Student: Yes! [adi agulha bl arabi: Can I say it in Arabic?]

- Lecturer: Yes.

- Student: Cohesion [yani trabt aljomal wa yakoon bainaha: means that sentences are connected to each other by ] linking words, [bs: while] coherence [ai altrabt adalali yani alma'ana: coherence means the meaning.]

- Lecturer: Yes, exactly.

There was limited use of Arabic in all classes observed. The researchers did not witness the lecturer using Arabic and noticed few mispronunciations by the participants. When students did mispronounce words, the lecturer offered an indirect correction by pronouncing the word with a stressed tone. For example, when participants pronounced 'communication' as (communicaish) and 'authentic' as (authenic), the lecturer repeated the words with correct pronunciation and stressed tones.

Overall, the data collected from the classroom observations showed that virtual classrooms can play a significant role in enhancing EFL students' communication skills. The data were analysed thematically by the researcher, and the analysis was based on students' oral interactions in the four virtual sessions, where audio calls were the main means of interaction. The themes were related to students' engagement, lecturer-student interaction, student-student interaction and students' linguistic issues.

In sum, analyses of the results highlight the common issues students face when practising oral communication. These issues stem from students' lack of confidence, anxiety about making mistakes, and insufficient vocabulary. Therefore, students felt that virtual classrooms played a significant role in enhancing their communication skills because they provided a more relaxed and comfortable environment. However, students also agreed that the lack of face-to-face communication had a negative effect on their interactions. The classroom observation data suggest that virtual classrooms can help improve students' communication skills. Students showed positive engagement in their interactions with the lecturer and their peers. Additionally, linguistic issues related to pronunciation and language interference were observed.

\section{Discussion}

\subsection{Discussion}

This study was conducted to investigate the effectiveness of virtual classrooms in enhancing oral communication skills from the perspective of 43 undergraduate EFL students. The data were gathered from a questionnaire distributed to the students to identify their oral communication problems and determine how they perceive the effectiveness of virtual classrooms in enhancing their communication skills. The researcher observed part of the sample in different virtual classrooms to compare students' perceived and actual performances. 


\subsubsection{What Common Problems Do Students Face in Oral English Communication}

The first section of the questionnaire was designed to examine students' oral communication problems. Participants expressed generally neutral attitudes towards the common issues they experience when communicating in English. The questionnaire revealed that a lack of confidence and anxiety about making mistakes are major obstacles for students when communicating in English, and students agreed that insufficient vocabulary hinders them from communicating effectively in English. These findings are similar to those of Cheekeong et al. (2014), which showed that $60 \%$ of participants did not take part in class discussions due to their lack of vocabulary, lack of confidence and fear of being judged negatively. The study confirmed that students' lack of confidence in their communicative and linguistic abilities would limit their oral English practice. Therefore, language teachers should provide a relaxing environment for their students and encourage them to speak regardless of the oral mistakes they might make.

The quantitative analysis shows that students have a neutral attitude towards the phonological and structural issues that hinder communication. These findings contradict those of Abu Alyan (2013), who asserted that pronunciation is a barrier to student participation in classroom discussions. Surprisingly, students did not consider teaching methodologies to be an obstacle to oral communication; the findings revealed that students have a neutral attitude towards teaching methodologies and activities. This result contradicts the findings of Cheekeong et al. (2014), who showed that teaching methodologies are one of the main factors affecting oral skills practice in the classroom. This research might conclude that the responsibility for developing oral skills lies with the learners themselves.

5.1.2 What are Students' Perceptions of the Effectiveness of Virtual Classes in Enhancing Their English Communication Skills

The second section of the questionnaire was designed to examine students' perceptions of the effectiveness of virtual classrooms in enhancing their communication skills. Generally, the findings show that the majority of students have a positive attitude towards virtual classrooms, which supports previous studies (Salbego \& Tumolo, 2015; Banditvilai, 2016; AlQahtani, 2019). The results revealed that virtual classes are more comfortable and convenient than traditional classrooms, and students agreed that virtual classrooms give them more confidence to speak and participate in discussions. This is consistent with AlQahtani's (2019) study of undergraduate EFL students, where participants stated that they felt more confident speaking in virtual classrooms than in face-to-face settings. Similarly, Cong-Lem (2018) observed that web-based technology provides a favourable environment for increasing student interactions. These findings suggest that practising oral English in traditional settings can be stressful for EFL students; a virtual environment may be more suitable due to the lack of face-to-face interactions, which makes it easier to practise. Therefore, teachers are advised to use virtual classrooms as a tool to help students improve their communication skills. When students are relaxed, they will freely interact with their instructors and classmates, which will positively impact their confidence, resulting in improved communication skills.

Moreover, the questionnaire revealed that students felt virtual classrooms had a positive impact on their motivation and engagement in classroom discussions. This could indicate that when students are relaxed and less stressed, their motivation and engagement increase. Furthermore, students displayed neutral attitudes towards their preference for regular or virtual classes. These findings are in contrast with the results of a study conducted by Istifci (2017), where the majority of participants agreed that they prefer traditional classrooms because it is easier for them to communicate with teachers and classmates. This may indicate that students' preferences are related to their learning style and personality; combining the two teaching models may address this.

Despite students' positive attitudes towards virtual classrooms, the majority of students disagreed on their effectiveness in helping them recognise their oral mistakes. This result may indicate that feedback is essential in helping students understand their mistakes. In addition, students felt that the lack of face-to-face interaction had a negative impact on their communication in virtual classrooms. These findings are similar to Banditvilai (2016), who noted that a lack of face-to-face communication may affect the interaction between teachers and students. Çakýroglu (2014) asserted that eye contact and body language play a significant role in face-to-face communication. Therefore, it was expected that the lack of certain components would affect the communication process.

\subsubsection{Are Virtual Classes Effective in Enhancing EFL Students' Communication Skills}

The current study suggests that virtual classrooms may play a significant role in enhancing EFL students' communication skills and that using virtual classrooms to enhance oral skills is a viable option. Therefore, virtual classrooms can be a valuable tool for practising oral communication skills. This result is in line with Hamouda (2020), whose study showed that the experimental group achieved a significant improvement in their oral skills after taking virtual classes. The students showed a high level of engagement, which was demonstrated through 
their oral interactions during the sessions. This can be interpreted as a willingness to participate, as evidenced by students' questions and responses to the lecturer and classmates. Most students responded quickly to the lecturer's questions, which can indicate that virtual classrooms offer a more relaxed environment. This aligns with students' opinions that virtual classrooms are more comfortable. Additionally, the current study's findings align with Salbego and Tumolo's (2015) study, where participants expressed that they felt more comfortable speaking in online classrooms. Asking questions was the most frequently used technique to initiate conversations between the lecturer and students during the sessions. Asking questions can be an effective way to encourage students to speak and practise their oral communication skills. According to Alshahrani (2016), asking questions promotes mutual communication between the teacher and students because questions require responses. The current study indicates that the question-and-answer technique is an effective way to enhance communication in virtual classrooms. The questions should vary from short answers to those that encourage further expression.

Various strategies can enhance oral communication skills in virtual classrooms. Presentations and role plays improve students' communication skills by providing practice opportunities; Khambayat (2017) stated that these strategies are effective in enhancing EFL students' communication skills. In Session 3, students were asked to perform a role play and in Session 4, they were tasked with giving a presentation about a language learning app. These strategies were effective in the virtual classroom because they gave students more opportunities to speak and communicate with their peers. The study results show that practising oral skills in a virtual classroom using strategies such as presentations and role plays is a practical and effective way to improve communication skills. This result is supported by Fauzi and Hanifah's (2018) findings, which showed that presentations are a successful strategy for developing oral skills and improving student performance. However, students should be taught how to involve their classmates and incorporate communicative activities into their presentations to increase student interaction. For instance, in Session 3, the presentation included many activities, which increased students' opportunities to practise their communication skills. In Session 4, however, students' engagement was limited due to the lack of activities or questions in the presentation.

Overall, the study revealed that virtual classrooms can play a significant role in improving students' oral skills. It should be noted that teachers' and students' roles must be clearly defined in virtual classrooms. The teacher should act as a facilitator, encouraging students to practise their oral skills and promoting their engagement in virtual classes. Furthermore, the lack of face-to-face interaction, body language and eye contact can affect communication. Therefore, it is the lecturer's responsibility to provide opportunities suitable to the virtual environment for EFL students to practise their oral communication skills. The researchers also observed a few technical issues during the sessions. For instance, the voice of one of the students (Presenter 2) was not clear, which made it difficult for students to interact with the presenter. This is a common issue in online learning. Gedera (2014) noted that unexpected technical issues in synchronous virtual classrooms can affect students' performance. However, this issue was observed only once during the four sessions. Therefore, the study indicates that technical issues are not a major obstacle in virtual learning.

\subsection{Limitations of the Study}

The study included online lessons only; the students and the lecturer had no previous face-to-face meetings, which may have affected student performance as well as the study findings. In addition, classes were conducted via audio calls; using other means of communication, such as videoconferences, might also affect the findings. Moreover, the study was conducted with only female students; conducting the same study with male students may produce different results. Lastly, the study was conducted with undergraduate EFL students; different results may be achieved if the study is carried out on students at other educational levels.

\subsection{Pedagogical Implications}

In light of the current study's findings, some implications are presented below:

1) Virtual classrooms provide a favourable environment for students to practise their communication skills, which suggests that language instructors should incorporate communicative activities that are suitable for virtual classrooms into their lessons.

2) Virtual classrooms provide a wide range of opportunities for students to improve their communication skills, so students should use this as a practice tool.

3) Instructors should be aware of the importance of asking questions in encouraging students to express themselves and develop their communication skills.

4) Because there are no time or place limitations in virtual classrooms, language instructors can use this as a tool for further communication practice. 


\subsection{Suggestions for Further Research}

This study examined EFL students' perceptions of the effectiveness of virtual classes in enhancing their communication skills; further studies could focus on the teachers' perceptions of the same issues. In addition, this study used two data collection instruments: the questionnaire and classroom observations. Future studies could employ different instruments, such as interviews. This study investigated the effectiveness of virtual classrooms in enhancing EFL communication skills; a similar study could be conducted to investigate the effects of virtual classes on other EFL skills. Researchers are also advised to adapt this study to include a larger number of students, students at different educational levels or those in other geographical locations to expand the generalisation of the study.

\section{Conclusion}

The purpose of this study was to determine the effectiveness of virtual classrooms in enhancing undergraduate EFL students' oral communication skills. It also explored the major issues EFL students encounter when communicating in English. Based on the findings of the mixed methods study, virtual classrooms may have a positive impact on oral communication skills. The results indicated that students' major communication problems are related to insufficient vocabulary, confidence issues and the fear of making mistakes. Participants agreed that virtual classes provide a comfortable and convenient environment for practising their communication skills. Additionally, students felt more motivated, engaged and confident in speaking with lecturers and peers during online classes. These findings might encourage language instructors to take advantage of virtual classrooms to improve their students' communication skills.

Despite these positive results, the study highlighted some negative aspects of virtual classrooms. Students believed that the lack of face-to-face interaction affected their interpersonal communication. Technical problems can also hinder effective communication among students, although this was observed only once during the four sessions.

\section{References}

Abu Alyan, A. (2013). Oral communication problems encountering English major students: Perspectives of learners and teachers in Palestinian EFL university context. Arab World English Journal, 4(3), 226-238.

Abu Bakar, N. A., Latiff, H., \& Hamat, A. (2013). Enhancing ESL learners speaking skills through asynchronous online discussion forum. Asian Social Science, 9(9), 224-233. https://doi.org/10.5539/ass.v9n9p224

Al Hosni, S. (2014). Speaking difficulties encountered by young EFL learners. International Journal on Studies in English Language and Literature (IJSELL), 2(6), 22-30.

Al-Asmari, A. M., \& Khan, M. S. R. (2014). E-learning in Saudi Arabia: Past, present, and future. Near and Middle Eastern Journal of Research in Education, 2014(1), 1-11. https://doi.org/10.5339/nmejre.2014.2

Alhawiti, M. M. F. (2017). The effect of virtual classes on the student English achievement in Tabuk Community College. International Journal of Learning Teaching and Educational Research, 16(5), 90-101.

Alhmadi, N. S. (2014). English speaking learning barriers in Saudi Arabia: A case study of Tibah University. Arab World English Journal, 5(2), 38-53.

Aljadili, M. Z. (2014). The Effectiveness of Using Virtual Classes on Developing the Tenth Graders' Speaking Skills and Their Speaking Anxiety. Unpublished Master Thesis, Islamic University, Gaza, Palestine.

Al-Mahrooqi, R. (2012). English communication skills: How are they taught at schools and universities in Oman? English Language Teaching, 5(4), 124-130. https://doi.org/10.5539/elt.v5n4p124

Al-Qahtani, M. H. (2019). Teachers' and students' perceptions of virtual classes and the effectiveness of virtual classes in enhancing communication skills. Arab World English Journal, Special Issue: The Dynamics of EFL in Saudi Arabia, 223-240. https://doi.org/10.24093/awej/efl1.16

AlSaleem, B. I. (2018). The effect of Facebook activities on enhancing oral communication skills for EFL learners. International Education Studies, 11(5), 144-153. https://doi.org/10.5539/ies.v11n5p144

Alshahrani, A. (2016). Communicating authentically: Enhancing EFL students' spoken English via videoconferencing. CALL-EJ, 17(2), 1-17.

Alshumaimeri, Y. (2008). Perceptions and attitudes toward using CALL in English classrooms among Saudi secondary EFL teachers. The JALT Journal, 4(2), 29-46. https://doi.org/10.29140/jaltcall.v4n2.61

Alshumaimeri, Y. (2019). English language teaching in Saudi Arabia: An introduction. Riyadh: King Saud University Press. 
Alswilem, D. A. (2019). Saudi English teachers' use of technology in secondary classrooms: Perceptions, barriers, and suggestions for improvement. Advances in Language and Literary Studies, 10(6), 168-178. https://doi.org/10.7575/aiac.alls.v.10n.6p.168

Appel, C., \& Borges, F. (2012, Aug. 31-Sep. 3). Task Design for L2 Oral Practice in Audioblogs. Paper presented at the European Association for Computer-Assisted Language Learning Annual Conference, Nottingham, United Kingdom.

Banditvilai, C. (2016). Enhancing students' language skills through blended learning. Electronic Journal of e-Learning, 14(3), 220-229.

Berry, S. (2019). The Role of Video and Text Chat in a Virtual Classroom: How Technology Impacts Community. In J. Yoon \& P. Semingson (Eds.), Educational technology and resources for synchronous learning in higher education (pp. 173-187). IGI Global. https://doi.org/10.4018/978-1-5225-7567-2.ch009

Çakýroglu, Ü. (2014). Evaluating students' perspectives about virtual classrooms with regard to Seven Principles of Good Practice. South African Journal of Education, 34(2), 1-19. https://doi.org/10.15700/201412071201

CheeKeong, Y., Yassin, A. A., \& Abdulrahman, T. T. A. (2014). Oral communication problems of Yemeni high school EFL students in Malaysia. Journal of Applied Sciences, 14(24), 3620-3626. https://doi.org/10.3923/jas.2014.3620.3626

Clark, V. L. P., \& Ivankova, N. V. (2015). Mixed methods research: A guide to the field (vol. 3). Thousand Oaks, CA: Sage Publications.

Cong-Lem, N. (2018). Web-based language learning (WBLL) for enhancing L2 speaking performance: A review. Advances in Language and Literary Studies, 9(4), 143-152. https://doi.org/10.7575/aiac.alls.v.9n.4p.143

Danesh, A., Bailey, A., \& Whisenand, T. (2015). Technology and instructor-interface interaction in distance education. International Journal of Business and Social Science, 6(2), 39-47.

Fauzi, I., \& Hanifah, D. (2018). Developing students' speaking ability through PowerPoint presentation. In ASEAN/Asian Academic Society International Conference Proceeding Series (pp. 172-178). https://doi.org/10.32678/loquen.v11i02.864

Gedera, D. (2014). Students' experiences of learning in a virtual classroom: An activity theory perspective. International Journal of Education and Development using ICT, 10(4), 93-101.

Hamouda, A. (2020). The effect of virtual classes on Saudi EFL students' speaking skills. International Journal of Linguistics, Literature and Translation, 3(4), 175-204.

Hussein, E. T. (2016). The effectiveness of using Blackboard in improving the English listening and speaking skills of the female students at the University of Hail. Advances in Social Sciences Research Journal, 3(12), 81-93. https://doi.org/10.14738/assrj.312.2379

Istifci, I. (2017). Perceptions of Turkish EFL students on online language learning platforms and blended language learning. Journal of Education and Learning, 6(1), 113-121.

Khambayat, S. R. (2017). Developing effective communication skills in students. Scholarly Research Journal for Interdisciplinary Studies, 4(37), 8799-8817. https://doi.org/10.21922/srjis.v4i37.10829

Khamkhien, A. (2011). Quantitative and qualitative views of Thai EFL learners' learning oral communication skills. Academic Research International, 1(1), 90-103.

Manegre, M., \& Sabiri, K. A. (2020). Online language learning using virtual classrooms: An analysis of teacher perceptions. Computer Assisted Language Learning. https://doi.org/10.1080/09588221.2020.1770290

Montoute, R. (2013). 16 Essential Tips for Planning to Moderate a Virtual Classroom Event. CreateSpace Independent Publishing Platform.

Nordstrom, S. N. (2015). Not so innocent anymore: Making recording devices matter in qualitative interviews. Qualitative Inquiry, 21(4), 388-401. https://doi.org/10.1177/1077800414563804

Pan, C. C., \& Sullivan, M. (2005). Promoting synchronous interaction in an eLearning environment. Technical Horizons in Education Journal, 33(2), 27-30.

Parker, M. A., \& Martin, F. (2010). Using virtual classrooms: Student perceptions of features and characteristics in an online and a blended course. MERLOT Journal of Online Learning and Teaching, 6(1), 135-147. 
Poongodi, A., \& Periasamy, J. K. (2020). Enhancing English speaking skills of engineering students in virtual classroom. International Journal of Emerging Trends in Engineering Research, 8(10), 7474-7475. https://doi.org/10.30534/ijeter/2020/1288102020

Salbego, N. N., \& Tumolo, C. H. S. (2015). Skype classes: Teachers and students' perceptions on synchronous online classes in relation to face-to-face teaching and learning. International Journal of Language and Applied Linguistics, 1(3), 36-45.

Tazijan, F. N., Baharom, S. S., \& Shaari, A. H. (2016). Building communication skills through flipped classroom. Proceedings of ISELT FBS Universitas Negeri Padang, 4(1), 289-295.

Thakur, V. S., Al Mashani, S. M., \& Almashikhi, K. (2019). Enhancing communication skills of ESL/EFL learners through in-class Project-based tasks and activities: A pedagogical framework. Adalya Journal, 8(9), 1357-1368.

Wambui, T., Kibui, A., \& Gathuthi, E. (2012). Communication Skills vol.1. Lap Lambert Academic Publishing $\mathrm{GmbH} \& \mathrm{Co}$.

Yadav, G. (2016). Reflection on virtual classes: Spirit of the time. International Journal of Advanced Research, 4(4), 1162-1167. https://doi.org/10.21474/IJAR01/333

Yilmaz, O. (2015). The effects of "live virtual classroom" on students' achievement and students' opinions about "live virtual classroom" at distance education. Turkish Online Journal of Educational Technology-TOJET, 14(1), 108-115.

\section{Copyrights}

Copyright for this article is retained by the author(s), with first publication rights granted to the journal.

This is an open-access article distributed under the terms and conditions of the Creative Commons Attribution license (http://creativecommons.org/licenses/by/4.0/). 